ACTA THERIOLOGICA

Vol. 21, 29: 389-399, 1976

\title{
Body Weights of Apodemus sylvaticus in Iceland
}

\author{
S.-A. BENGTSON ${ }^{1}$, A. NILSSON ${ }^{2}$, S. NORDSTRÖM ${ }^{2}$ \\ \& S. RUNDGREN ${ }^{2}$
}

Bengtson S. A., Nilsson A., Nordström S. \& Rundgren S., 1976: Body weights of Apodemus sylvaticus in Iceland. Acta theriol., 21, 29: 389 -399 [With 2 Tables \& 4 Figs.].

Apodemus sylvaticus (L in n a e u s, 1758) is markedly larger in Iceland than in e.g. Central Europe. The mean weights of reproductive males varied between $32.4 \mathrm{~g}$ and $34.5 \mathrm{~g}$ in 1973 and $29.9 \mathrm{~g}$ and $33.5 \mathrm{~g}$ in 1974. In reproductive females the corresponding values were 28.8 $-30.7 \mathrm{~g}$ and $24.2-28.8 \mathrm{~g}$. The mean weights of subadult females were lower than for subadult males in all trapping periods. $100 \%$ sexual maturity was obtained at $26.0 \mathrm{~g}$ for males and $24.0 \mathrm{~g}$ for females. In spring-born animals there was a continuous growth from June to November, except for males and females being sexually active or pregnant in summer and then postreproductive in November. In overwintered animals the mean weight was stable during summer. The grand mean weight for each trapping period decreased during summer with $8 \%$ and $11 \%$ in 1973 and 1974 respectively. The summer decline of the grand mean weight seemed to be due to a disappearance of heavy individuals and recruitment of lighter ones.

$\left[{ }^{1}\right.$ Zool. Mus. \& Dept. Morphol., Syst. \& Anim. Ecol., Univ Bergen Muséplass 3, N-5014 Bergen, Norway. ${ }^{2}$ Dept. Anim. Ecol., Univ. Lund, S-223 62 Lund, Sweden]

\section{INTRODUCTION}

Three small rodent species occur in Iceland viz. Rattus norvegicus (B er k e n h o t, 1769), Mus musculus L in n a u s, 1758 and Apodemus sylvaticus (Linna e us, 1758). The first two species are only found in association with human dwellings. A. sylvaticus is the only small mammal in the field and consequently competition for food, cover, and space is entirely intraspecific. Moreover, predation within our study areas is small or absent. There are no native small-mammal predators, although feral cats from the nearby village were observed in our study area at Vík.

Hitherto there has been only a few papers concerning A. sylvaticus in Iceland dealing mainly with the taxonomy and ectoparasites (L u p t o n \& W y kes, 1938; S a e m unds son, 1939 and De ger bol, 1939). In this paper we describe and discuss the patterns of weight changes in two Icelandic populations of $A$. sylvaticus. The data have been obtained during long-term ecological investigations that are still in progress. 


\section{STUDY PLOTS AND TRAPPING}

The study was carried out in two plots, which differ markedly from each other with respect to climate, vegetation, food supply and density of the Apodemus population.

A. Vik $63^{\circ} 25^{\prime} \mathrm{N} ; 19^{\circ} \mathrm{W}: 500 \mathrm{~m}$ southwest of the village of Vík in southern Iceland on a talus slope facing the sea. The vegetation is characterized by dense, $1.5-2 \mathrm{~m}$ high Angelica archangelica $\mathrm{L}$. in one part of the plot, which gradually changes to a rich herb meadow dominated by Ranunculus acris L., Potentilla anserina L., Rumex acetosa L. and Anthoxanthum odoratum L. in the other part. In the summer, the field layer is extraordinarily luxuriant and supports an abundant and diverse insect fauna. The climate at Vik is maritime with an annual mean precipitation of $2250 \mathrm{~mm}$. The monthly mean temperature of the coldest months, January and February, is $1.2^{\circ} \mathrm{C}$ and the warmest month, July has a mean of $11.3^{\circ} \mathrm{C}$ (E y thors S on \& Sigtrygg s o n, 1971).

B. Mývatn $65^{\circ} 35^{\prime} \mathrm{N} ; 17^{\circ} \mathrm{W}$ : Near Lake Mývatn, northeastern Iceland, within an alpine birch forest, Betula pubescens Ehrh., on a lava field. The field layer is poor with Betula nana L., Arctostaphylos uva ursi (L.) Spreng., and Empetrum nigrum L. as dominants. On scattered spots the lava is bare. Seed production of the scattered herbs and grasses is presumably low, as is the abundance of terrestrial insects and other invertebrates. The climate at Mývatn is more continenta: The yearly mean precipitation is about $400 \mathrm{~mm}$. The mean temperature of the coldest and warmest months is $-4.2{ }^{\circ} \mathrm{C}$ and $10.2^{\circ} \mathrm{C}$ respectively (E y th or s on \& Sigtryggsson, 1971).

During 1973 and 1974 the periods when weighing was performed were;

Vík: 1973: $1-5$ June, 17-19 June, 4-8 July, 20-29 August, $4-8$ November; 1974: 20-30 June, 22-26 July, 15-20 August, 29 October -4 November.

Mývatn: 1973; 18-24 April, 8-12 July, 31 August - 5 September, 29 October 2 November; 1974: 2-6 July, 28-30 July, 23-28 August, 5-11 November.

Multiple-catching live-traps were placed in a permanent grid system covering approximately 0.87 ha ( 84 traps) at Vík and 2.50 ha (81 traps) at Mývatn. The traps were examined at least every morning and every evening.

Each animal was individually marked by toe-clipping; not more than two toes were cut on each foot. External evidence of sex, age and sexual activity (size of testes, swollen vulva, perforate vagina, lactation or visible pregnancy) was used in classification of trapped animals. Such criteria have obvious shortcomings, but are sufficient to obtain a rough picture of the reproductive status and composition of the populations. The animals were classified as juveniles, subadults, reproductives or postreproductives. The animals were weighed in the field in polyethene bags with an accuracy of $\pm 1 \mathrm{~g}$. The mean weights were calculated for individuals caught twice or more during the same trapping period. On some occasions heavy wind and rain disturbed the weighing procedure and for some individuals we were therefore not able to obtain reliable values. Such individuals have been excluded.

At Vík a total of 8400 trap examinations yielded 2681 catches and 456 different individuals were caught on average 5.9 times each. At Mývatn the number of trap examinations was 3192 and 78 individuals were caught 199 times; i.e. on average 2.6 catches per individual.

\section{THE POPULATIONS}

The Vik population was dense during all trapping periods. In November 1973 and 1974 there were about 160 and 120 individuals per ha respectively. During the 
summer months the density varied between about 70 and 100 individuals per ha except in June 1974 when the density exceeded even the autumn figures. In the Mývatn plot the density was low, with a maximum of about 8 individuals per ha in November 1973. According to capture-recapture data in the Mývatn plot very few individuals were stationary throughout the reproduction season. Most individuals were caught once or twice, which suggests that they only occasionally visited the plot.

At Vik juveniles were found in June, July and August, but at Mývatn in August only. In November all individuals were sexually inactive in both areas. There is no evidence of winter reproduction.

The pronounced differences in density of the two populations are probably due to differences in food supply. The Vík area with its high Angelica seed production and abundance of invertebrates offers better conditions for A. sylvaticus than that at Mývatn.

\section{RESULTS}

\subsection{Variation in Body Weights}

Fig. 1 gives the weights of animals of different sexes and age classes at different times of the years at Vík. The mean weights of subadult males and females increased with $36 \%(24.7-33.5 \mathrm{~g})$ and $25 \%(23.0-$ $28.8 \mathrm{~g}$ ) respectively from November to June the following year, when all were reproductive. During summer, when sexual activity was high, the weight changes of reproductives were small, except for females in 1974. During this period the reduction in mean weight for this group was $16 \%$.

The mean weight of reproductive males was higher than that of females in all trapping periods, the differences being statistically significant in June $1973(t=4.85 ; P<0.001)$, July $1973(t=2.75 ; 0.05>P>0.01)$, June $1974(t=6.00 ; P<0.001)$ and August $1974(t=2.03 ; P \approx 0.05)$. There were no statistically significant weight differences between postreproductive males and females in 1973 or 1974.

The highest weight of subadults were obtained in August 1974 and November $1973(24.7 \mathrm{~g})$. In general the mean weights of corresponding trapping periods were markedly lower in 1974 than in 1973. The number of subadult females was low throughout the summers and statistically significant differences between the sexes of subadults were obtained only in one summer month, August, $(t=11.51 ; P<0.001)$ and in November $1973(t=13.60 ; P<0.001)$ and $1974(t=8.60 ; P<0.001)$.

During the study the weights of trappable juvenile males and females ranged $8.0-20.5 \mathrm{~g}$ and $6.0-19.0 \mathrm{~g}$ in 1973 and 1974 respectively. The mean weights varied considerably between the trapping periods and no statistically significant differences between the sexes were obtained in any of them. Individuals weighing more than $40 \mathrm{~g}$ were obtained in June and July 
1973 and in June 1974; the highest value, $42.0 \mathrm{~g}$ was recorded in July 1973 in a reproductive male. In corresponding periods the mean weights of the different sexes and ages were in general lower at Mývatn than at Vík (Table 1). The differences were not statistically significant in summer due mainly to the limited samples obtained at the Mývatn area. In November, however, statistically significant differences between the sexes was found for females in $1973(t=6.02 ; P<0.001)$ and for males in 1974 $(t=3.13 ; 0.01>P>0.001)$.

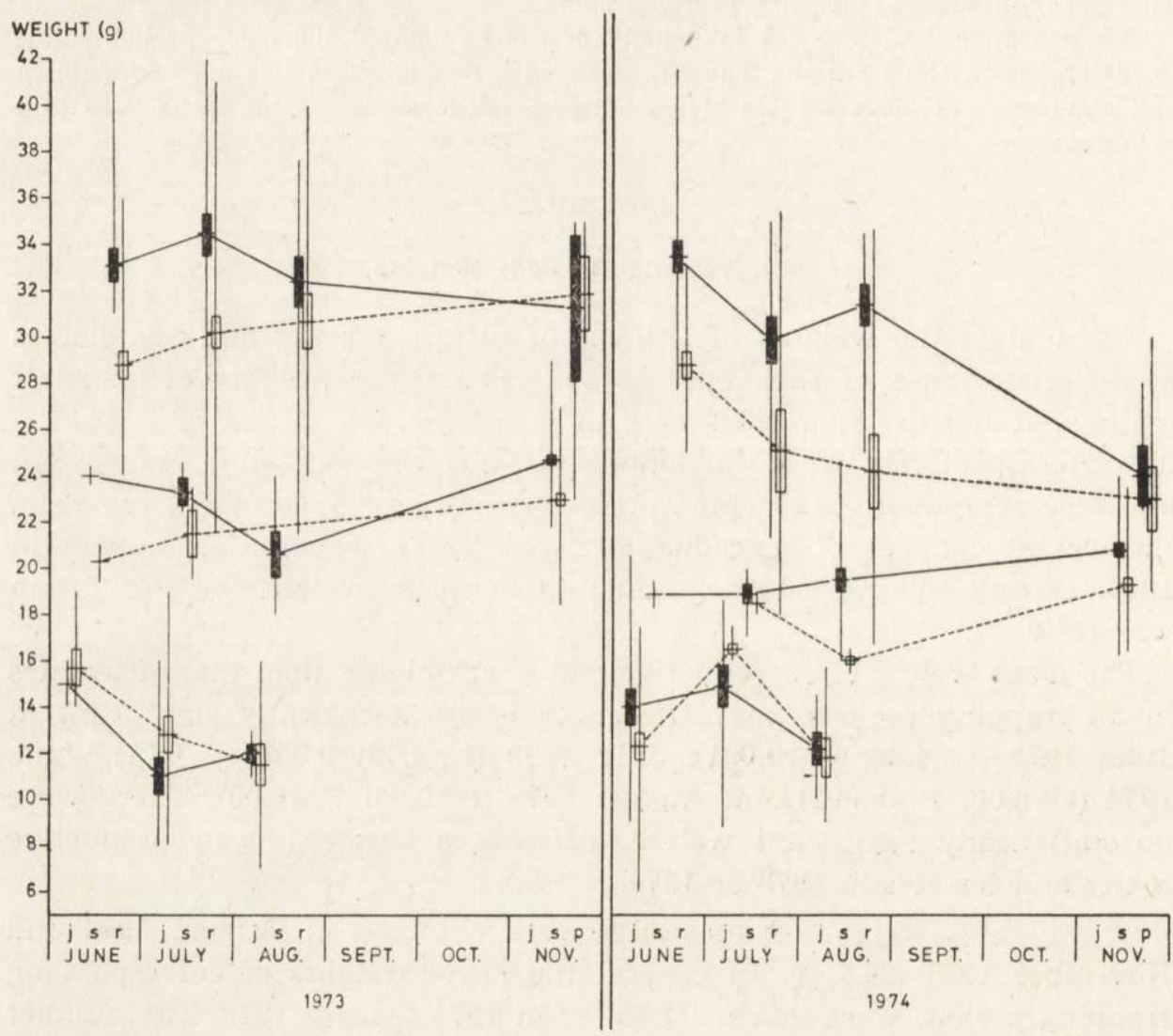

Fig. 1. Variation in body weights of male (filled rectangles) and female (unfilled rectangles) Apodemus sylvaticus at the Vík plot. Top row: reproductive animals (r) (in November postreproductive). Middle row: subadults (s). Lower row: juveniles (j). Observed ranges, means and $\mathrm{SE}$ are shown.

The grand mean weight for each trapping period in the Vík population showed the same pattern in 1973 and 1974. The mean weight decreased during summer and was about the same in November as in August (Fig. 2). However, in 1974 , the values of corresponding months were $3-4 \mathrm{~g}$ 
Table 1

Variation in body weight of Apodemus sylvaticus at the Mývatn plot.

\begin{tabular}{|c|c|c|c|c|c|c|c|c|}
\hline & & & 73 & & & 1974 & & \\
\hline & April & July & Sept. & Nov. & July I & July II & Aug. & Nov. \\
\hline & & & & males & & & & \\
\hline $\mathrm{n}$ & 8 & 2 & 10 & 12 & 3 & 4 & 13 & 11 \\
\hline $\min$ & 26.7 & 23.0 & 15.0 & 18.5 & 21.0 & 20.0 & 12.3 & 14.5 \\
\hline $\max$ & 37.0 & 34.0 & 37.0 & 34.0 & 24.0 & 32.0 & 32.0 & 28.3 \\
\hline$\overline{\mathrm{x}}$ & 30.5 & 28.5 & 26.9 & 24.6 & 22.2 & 24.3 & 20.5 & 20.2 \\
\hline $\mathrm{SE}$ & 1.18 & 5.50 & 2.28 & 1.54 & 0.93 & 2.72 & 1.65 & 1.25 \\
\hline & & & $\mathrm{Al}$ & female: & & & & \\
\hline $\mathrm{n}$ & 1 & & 8 & 8 & & 1 & 2 & 4 \\
\hline $\min$ & & & 13.5 & 13.5 & & & 28.5 & 16.8 \\
\hline $\max$ & & & 34.3 & 32.0 & & & 34.0 & 21.7 \\
\hline $\bar{x}$ & 24.0 & & 18.6 & 21.0 & & 23.0 & 31.3 & 19.7 \\
\hline $\mathrm{SE}$ & & & 1.94 & 1.95 & & & 2.75 & 1.05 \\
\hline & & & All mal & and $f$ & ales & & & \\
\hline $\mathrm{n}$ & 9 & 2 & 18 & 20 & 3 & 5 & 15 & 15 \\
\hline $\min$ & 24.0 & 23.0 & 13.5 & 13.5 & 21.0 & 20.0 & 12.3 & 14.5 \\
\hline $\max$ & 37.0 & 34.0 & 37.0 & 34.0 & 24.0 & 32.0 & 34.0 & 28.3 \\
\hline$\overline{\mathrm{x}}$ & 29.8 & 28.5 & 23.2 & 23.2 & 22.2 & 24.0 & 21.9 & 20.0 \\
\hline SE & 1.26 & 5.50 & 1.94 & 1.24 & 0.93 & 2.12 & 1.74 & 0.97 \\
\hline
\end{tabular}

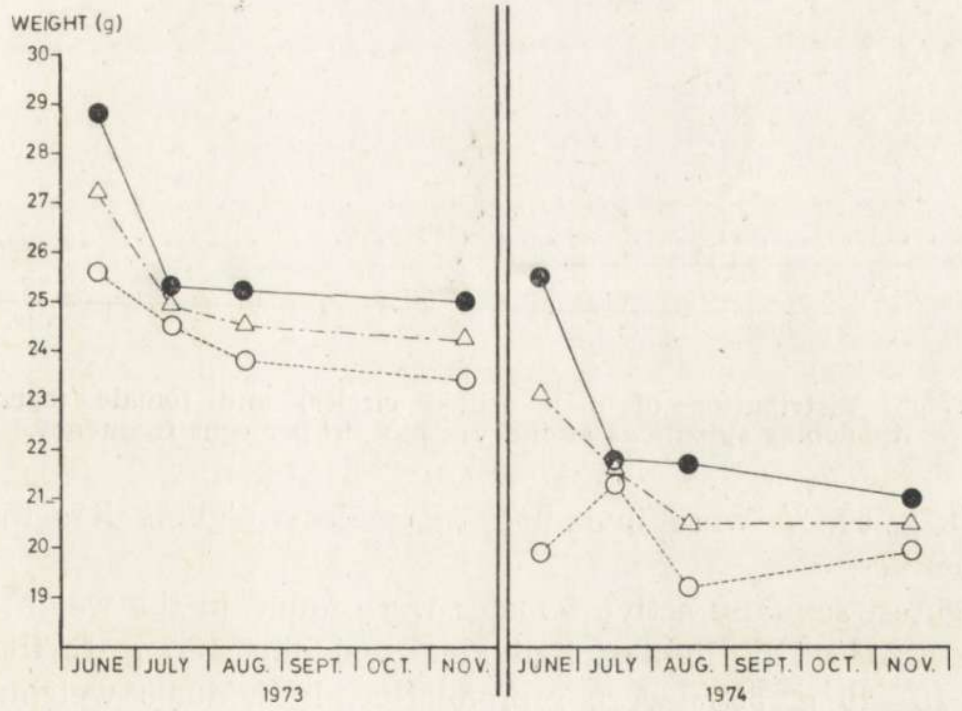

Fig. 2. Variation in grand mean weights of Apodemus sylvaticus at the Vík plot. - males, $\bigcirc$ females, $\Delta$ males. + females.

lower than in 1973. The mean weight of all individuals decreased during the summers of 1973 and 1974 by $8 \%$ and $11 \%$ respectively.

The weight range showed a decreasing trend from early summer to autumn (Fig. 3). In late summer there were relatively few heavy indi- 
viduals compared with June, whereas the young production seemed to be as high in August as in June. The weight range in November was narrow due to absence of both heavy and light individuals. During summer the samples showed a bimodal and trimodal weight distribution. In November the weights of both sexes appeared to be unimodally distributed.

Reproductive males in June had a minimum weight of $27.7 \mathrm{~g}$. Later in the summer the minimum weight decreased to $21.3 \mathrm{~g}$ in July (1974) and $21.5 \mathrm{~g}$ in August (1973) (Fig. 1). In summer, males with a body weight of $26 \mathrm{~g}$ or more may be considered sexually active. The heaviest male still bearing its juvenile pelage weighed $20.5 \mathrm{~g}$. In the weight class
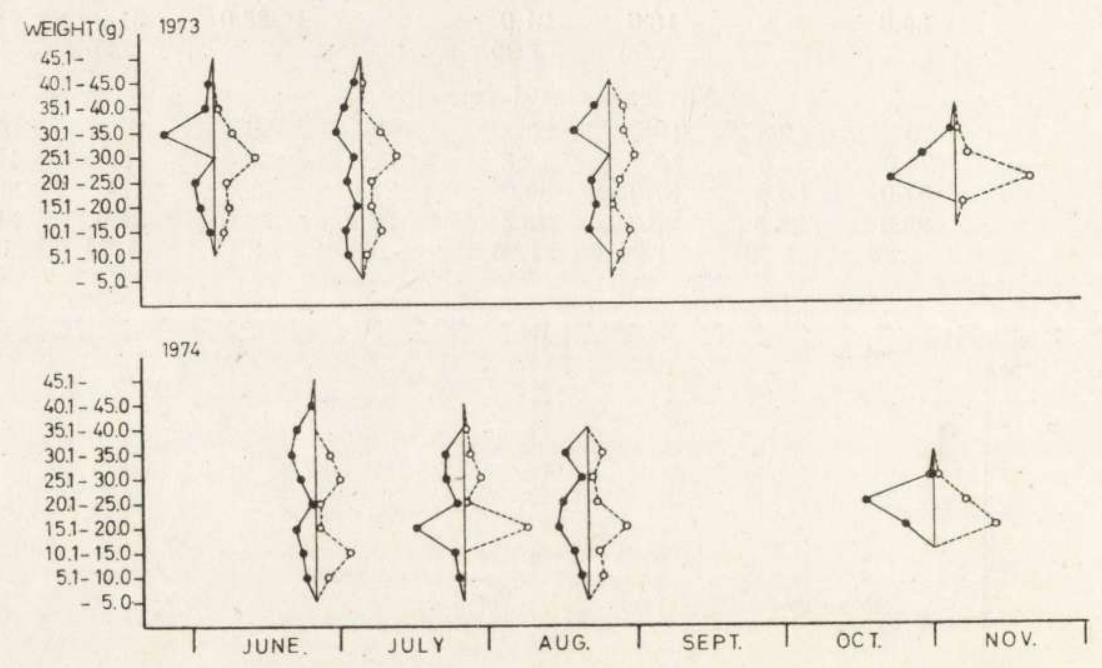

Fig. 3. Weight distribution of male (filled circles) and female (open circles) Apodemus sylvaticus at the Vik plot, in per cent frequency.

of $16-18 \mathrm{~g}, 57.1 \%$ were juveniles. Allımales weighing less than $16 \mathrm{~g}$ were juveniles.

The lightest sexually active females were found in the weight class of $16-18 \mathrm{~g}(21.1 \%)$; the lightest individual weighing $16.7 \mathrm{~g}$. In the weight class of $18-20 \mathrm{~g}, 50 \%$ were reproductive. Individuals weighing more than $24.0 \mathrm{~g}$ were reproductive. The two heaviest juvenile females weighed $19.0 \mathrm{~g}$. In the weight class $16-18 \mathrm{~g}, 68.4 \%$ were juveniles. Females weighing less than $14 \mathrm{~g}$ were all juveniles.

\subsection{Individual Weight Changes}

In overwintered males the mean weights were stable throughout the summer (Table 2). The differences between different trapping periods. 
were largest $(1.9 \mathrm{~g})$ between June and July 1973 . In 1974 the differences did not exceed $0.6 \mathrm{~g}$. The differences in mean weight between consecutive trapping periods for these individuals were not statistically significant. Corresponding months of the two years revealed significant differences only for July $(t=3.08 ; 0.01>P>0.001)$.

In spring-born males (individuals becoming sexually mature during summer were excluded) there was a continuous growth throughout the summer, the differences in mean weights being statistically significant between consecutive trapping periods in 1974 (Table 2). The growth rate decreased considerably at $18-20 \mathrm{~g}$. Of the males born in spring and

Table 2

Weight variation and mean weight changes during the summers of 1973 and 1974 in two different cohorts of males.

\begin{tabular}{|c|c|c|c|c|c|}
\hline Year, & Month & $\mathrm{n}$ & $\mathrm{x}_{\min }-\mathrm{X}_{\max }$ & $\overline{\mathrm{x}} \pm \mathrm{SE}$ & $t$-test \\
\hline & \multicolumn{5}{|c|}{ A. Overwintered individuals } \\
\hline \multirow[t]{3}{*}{1973} & June & 17 & $28.0-41.0$ & $33.4 \pm 0.7$ & \\
\hline & July & & $29.0-42.0$ & $35.3 \pm 0.9$ & \\
\hline & August & 7 & $30.5-37.7$ & $33.8 \pm 1.0$ & \\
\hline \multirow[t]{4}{*}{1974} & June & 9 & $25.7-36.0$ & $30.7 \pm 1.2$ & \\
\hline & July & 9 & $27.3-34.1$ & $30.3 \pm 0.9$ & \\
\hline & August & 6 & $27.7-34.5$ & $30.9 \pm 1.1$ & \\
\hline & \multicolumn{5}{|c|}{ B. Individuals born in spring the same year } \\
\hline \multirow[t]{2}{*}{1973} & $\begin{array}{l}\text { June } \\
\text { July }\end{array}$ & $\begin{array}{l}8 \\
8\end{array}$ & $\begin{array}{l}14.0-24.0 \\
20.5-25.5\end{array}$ & $\begin{array}{l}20.0 \pm 1.2 \\
23.3 \pm 0.5\end{array}$ & \multirow{6}{*}{$\begin{array}{l}t=6.65 ; P<0.001 \\
t=2.85 ; 0.01>P>0.001 \\
t=3.51 ; 0.01>P>0.001\end{array}$} \\
\hline & August & 1 & & 23.0 & \\
\hline \multirow[t]{4}{*}{1974} & June & 15 & $9.0-18.8$ & $13.7 \pm 0.8$ & \\
\hline & July & 15 & $16.5-21.3$ & $18.4 \pm 0.3$ & \\
\hline & August & 14 & $16.0-23.0$ & $19.5 \pm 0.5$ & \\
\hline & November & 7 & $20.0-23.0$ & $21.0 \pm 0.4$ & \\
\hline
\end{tabular}

recaptured in summer only two out of seven had become sexual mature. The weights of both exceeded the mean of other males born the same year.

Fig. 4 shows the weights of all individuals trapped in all trapping periods at Vík in 1974; all born in spring of the same year. Almost all individuals increased in weight from one trapping period to another and reached their maximum weights in November. Two females, however, decreased in weight from August to November. One of these was pregnant in August when the highest weight was recorded. One of the males decreased in weight from June to July, but later reached a maximum in November. 
In November 1973, there was no statistically significant difference in mean weights between those individuals which were recaptured the following June (surviving the winter) and those which were not (dead or emigrated).

\section{DISCUSSION}

The high weights of Icelandic A. sylvaticus recorded by L u p ton \& W ykes (1938) was of the some order as found in the present study.
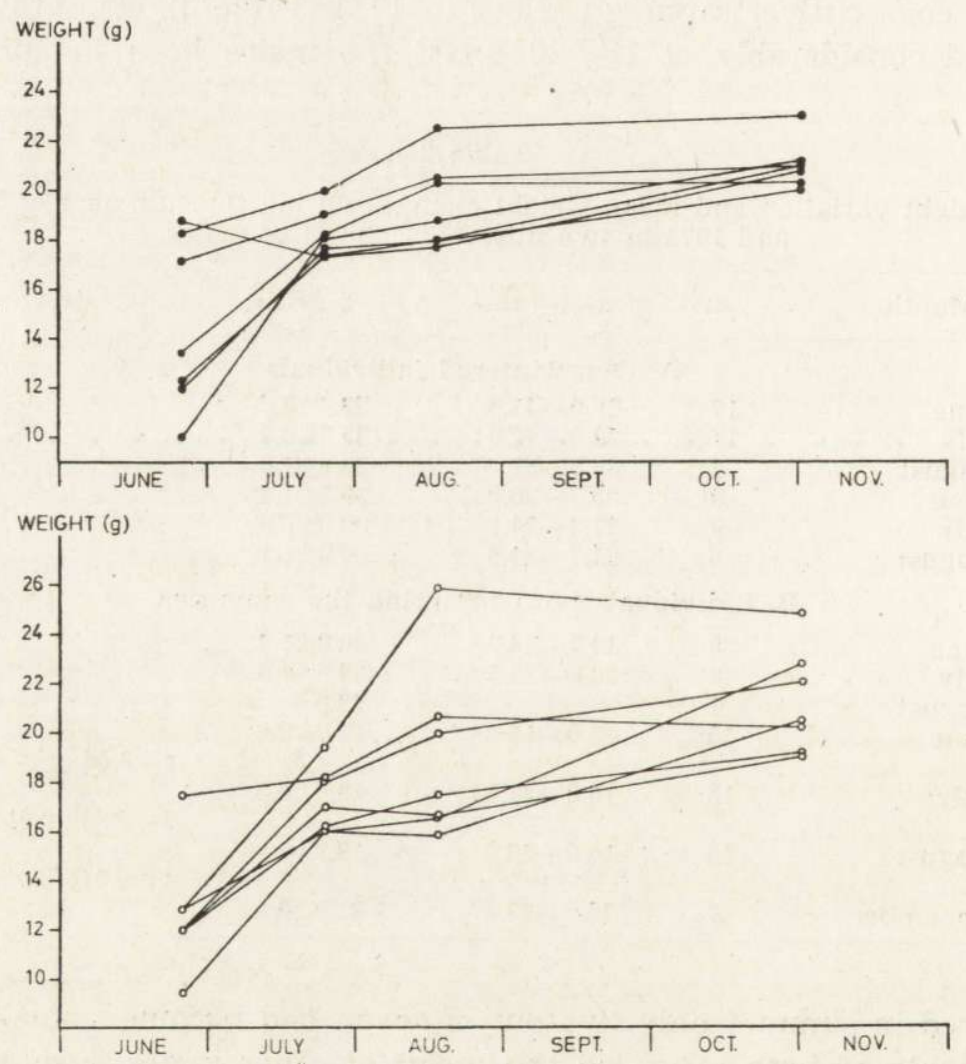

Fig. 4. Weight development of individual Apodemus sylvaticus at the Vík plot. males, $\bigcirc$ females.

Reproductive males are, for instance, on average $10 \mathrm{~g}(43 \%)$ heavier than those in Central Europe (P elika n, 1967). Also in Scandinavia and in England the weights of $A$. sylvaticus are considerably lower than in Iceland (B e r g s t e d t, 1965; $\mathrm{H}$ a n s s o n, 1971; M ill e r, 1958; W a t t s, 1968). Large and heavy forms of A. sylvaticus are not restricted to Iceland. B o y d (1959) reported mean weights of males on the island of 
St. Kilda in the Hebrides of about $40 \mathrm{~g}$ in early summer. The maximum individual weight was $56.5 \mathrm{~g}$ found in a male $(42.0 \mathrm{~g}$ in Iceland).

Seasonal variations in body weights have been found in many smallmammal populations in northern regions (e.g. Miller, 1958; B e r gstedt, 1965; Hansson, 1971; Hyvärinen \& Heikura, 1971; Iverson \& Turner, 1974). Such variations have mostly been explained by seasonal changes in the frequencies of heavy and light individuals and/or differences in individual growth. Thus, in a population of Microtus pennsylvanicus Ord. in Minnesota, I vers on \& Turner (op. cit.) found the mean weight decrease in autumn and winter to be caused by a combination of recruitment of lighter individuals and individual weight losses. In our material individual weight losses from late summer to autumn was found only in two females, and was probably due to pregnancy in August (Fig. 4). The decline of the mean weight of the population at Vík therefore seems to be due to a disappearence of heavy individuals and a recruitment of lighter ones. There was a marked weight increase from November to June. Unfortunately we were not able to record the pattern of this increase in weight, but it is probably associated with the start of sexual activity in spring as in e.g. Microtus arvalis (Pallas, 1779) (Reichstein, 1964). This is evidenced the fact that the mean weight of male individuals being sexually active in their first summer was higher than in sexually inactive males of approximately the same age.

The mean weight of males of different sexual development stages and different trapping periods was always higher (however, not always significantly so) than in females except for postreproductive animals in November 1973 , when the females weighed slightly more. The differences were less pronounced in juveniles and subadults than in reproductive animals. This is in accordance with observations in e.g. Scandinavia and England (B erg s ted t, 1965 and Mille r, 1958), but is not consistent with data from South Moravia, Czechoslovakia (P e li k a n, 1967).

Population densities and mean weights of certain developmental stages differed between the two plots studied. As pointed out above, density differences are probably caused by differences in food supply. This may also be part of the reason for the observed differences in mean weights of the two Apodemus populations.

In overwintered animals the differences in mean weight during the summer was small. The spring generation, however, showed a continuous growth throughout the summer (Table 2). This is not in accordance with the findings of e.g. Schwarz et al. (1964), who found that both generations showed a weight maximum approximately at the same time in the summer. 
Acknowledgements: This paper is part of a more extensive study of the dispersal and ecology of certain invertebrates and rodents in Iceland. The project received financial support from the Nordic Council for Terrestrial Ecolugy, the Swedish Natural Science Research Council and the Norwegian Research Council for Science and the Humanities. We also express our gratitude to Dr. P. H Enckell and Dr. M. Mo o n for their valuable comments on the manuscript.

\section{REFERENCES}

1. B ergstedt B., 1965: Distribution, reproduction, growth and dynamics of the rodent species Clethrionomys glareolus (Schreber), Apodemus flavicollis (Melchior) and Apodemus sylvaticus (Linné) in southern Sweden. Oikos, 16: $132-160$.

2. B o yd J. M., 1959: Observations on the St. Kilda field-mouse Apodemus sylvaticus hirtensis Barrett-Hamilton. Proc. zool. Soc. Lond. 133: 47-65.

3. Degerbøl M., 1939: The field mouse of Iceland, its systematic position (Apodemus sylvaticus grandiculus subsp. nov.) and biology. [In: "The Zoology of Iceland«]. Vol. 4, part 76: 39-52.

4. Eythorss on J. \& Sigtryggs on H., 1971: The climate and weather of Iceland. [In: "The Zoology of Iceland«]. Vol. 1, part 3: 1-62.

5. Hanss on L., 1971: Small rodent food, feeding and population dynamics. Oikos, 22: 183-198.

6. Hyvärinen H. \& Heikura K., 1971: Effects of age and seasonal rhythm on the growth patterns of some small mammals in Finland and in Kirkenes, Norway. J. Zool., Lond., 165: 545-556.

7. Ivers on S. L. \& Turner B. N., 1974: Winter weight dynamics in Microtus pennsylvanicus. Ecology, 55: 1030-1041.

8. Lupton P. \& Wykes U., 1938: The field mice of Iceland. J. Anim. Ecol., 7: $22-26$.

9. Miller R. S., 1958 A study of a Wood Mouse population in Wytham Woods, Berkshire. J. Mammal., 39: 477-493.

10. Pelikan J., 1967: Variability of body weights in three Apodemus species. Zool. Listy, 16: 199-220.

11. Reichstein H., 1964: Untersuchungen zum Körperwachstum und zum Reproduktionspotential der Feldmaus. Z. wiss. Zool., 170: 112-222.

12. Sa emundss on B., 1939: Mammalia [In: "The Zoology of Iceland"]. Vol. 4, part 76 .

13. Schwarz S. S., Pokrovski V. A., Istchenko V. G., Olenjev V. G., Ovtschinnikova N. A. \& Pjastolova O. A., 1964: Biological pecularities of seasonal generations of rodents, with special reference to the problem of senescence in mammals. Acta theriol. 8, 2: 11- 43.

14. Watts C. H. S., 1968: The foods eaten by wood mice (Apodemus sylvaticus) and bank voles (Clethrionomys glareolus) in Wytham Woods, Berkshire. J. Anim. Ecol., 37: 25-41.

Accepted, February 2, 1976 


\section{S.-A. BENGTSON, A. NILSSON, S. NORDSTRÖM i S. RUNDGREN}

\section{CIĘŻARY CIAEA U MYSZY ZAROSLOWEJ Z ISLANDII}

\section{Streszczenie}

Mysz zaroślowa Apodemus sylvaticus (L inna e us, 1758) jest znacznie większa w Islandii niż np. w Europie Srodkowej. Sredni ciężar aktywnych płciowo samców waha się pomiędzy 32,4 a $34,5 \mathrm{~g}$ w 1973 roku i $29,9-33,5 \mathrm{~g}$ w 1974 roku. U rozmnażających się samic adpowiednie wartości wynoszą $28,8-30,7 \mathrm{~g}$ i $24,2-28,8$ g. (Ryc. 1 ). Sredni ciężar samic subadultus był niższy niż takichże samców, we wszystkich okresach odłowu. Wszystkie samice o ciężarze $26,0 \mathrm{~g}$ i samice powyżej $24,0 \mathrm{~g}$, osiągają dojrzałość płciową. Osobniki urodzone wiosną rosną nieprzerwanie od czerwca do listopada, za wyjątkiem samic i samców aktywnych płciowo. (Ryc. 4). U przezimków średni ciężar ciała był stały w ciągu lata (Tabela 2, Ryc. 2). Wartość średnia dla całej populacji zniżała się w ciągu lata o 8 i $11 \%$ odpowiednio w 1973 i 1974 roku (Ryc. 3). To letnie zniżenie wydaje się być powodowane ubywaniem cięższych osobników a przybywaniem $w$ to miejsce lżejszych zwierząt. 